\title{
An assessment of current and critical nitrogen and phosphorus losses from European agricultural soils
}

\author{
$\underline{\text { J. Kros }}^{\mathrm{a}}$, W. de Vries ${ }^{\text {a,b }}$, P.F.A.M. Römkens ${ }^{\text {a }}$, and J.C. Voogd ${ }^{\text {a }}$ \\ a Alterra, Wageningen University and Research Centre (WUR), PO Box 47, 6700 AA Wageningen, The \\ Netherlands \\ ${ }^{b}$ Environmental Systems Analysis Group, Wageningen University, PO Box 47, 6700 AA Wageningen, The \\ Netherlands \\ Email:hans.kros@wur.nl
}

\begin{abstract}
Since the early 1940s, European agriculture has intensified greatly, resulting in large inputs of nitrogen $(\mathrm{N})$ and phosphorus $(\mathrm{P})$ to soil by fertilizers and manure. This has led to an increase in crop growth and soil fertility in terms of elevated $\mathrm{N}$ and $\mathrm{P}$ contents. However, the increased application of fertilizers and manure also induced adverse effects, such as: (i) loss of biodiversity in natural ecosystems due to increased emission and deposition of ammonia, (ii) increased levels of nitrogen in drinking water reservoirs due to leaching of nitrate to ground water and (iii) eutrophication of surface waters due to increased runoff of $\mathrm{N}$ and $\mathrm{P}$. Main aim of this study therefore was to identify regions where $\mathrm{N}$ and $\mathrm{P}$ loads used for agricultural production lead to the adverse impacts listed above. This was assessed by comparing current $\mathrm{N}$ and $\mathrm{P}$ losses from agriculture with critical losses, calculated at a high spatial resolution for the entire European Union using the INTEGRATOR model. Current $\mathrm{N}$ and $\mathrm{P}$ losses were based on calculations using current detailed agronomic and biophysical data. Critical $\mathrm{N}$ and $\mathrm{P}$ losses were based on critical $\mathrm{NH}_{3}$ emissions, $\mathrm{NO}_{3}$ leaching rates, as well as $\mathrm{N}$ and $\mathrm{P}$ runoff rates. Critical $\mathrm{NH}_{3}$ emissions were related to national emission ceilings in view of biodiversity loss. Critical leaching and runoff levels were derived from critical $\mathrm{N}$ and $\mathrm{P}$ concentrations in view of drinking water quality and eutrophication, respectively. Calculated current (2010) $\mathrm{N}$ and $\mathrm{P}$ balances show that they are highly spatially variable and largely related to the livestock distribution. The critical $\mathrm{P}$ runoff to surface waters is most often exceeded followed by $\mathrm{N}$ runoff to surface waters and $\mathrm{NO}_{3}$ leaching to groundwater.
\end{abstract}

Keywords: $\quad \mathrm{N}$ and $\mathrm{P}$ balances, agriculture, nutrient losses, leaching, $\mathrm{NH}_{3}$ emission 


\section{INTRODUCTION}

Since the early 1940s, European agriculture has intensified greatly resulting in increasingly large inputs of nitrogen $(\mathrm{N})$ and phosphorus $(\mathrm{P})$ to soil by fertilizers and manure. Beneficial effects include both an increase in crop growth as well as soil fertility status in terms of $\mathrm{N}$ and $\mathrm{P}$ contents. However, the increased application of fertilizers and manure also induced unwanted side-effects including: (i) increased emission of ammonia and deposition on nearby ecosystems resulting in loss of biodiversity, (ii) elevated runoff of $\mathrm{N}$ and $\mathrm{P}$ resulting in eutrophication of nearby surface water, and (iii) increased leaching rates of nitrate to ground water affecting drinking water quality. Since most of these effects occur at local or regional level and are highly spatial variable, this requires spatially disaggregated balances rather than national balances to assess the local or regional impact.

In this study we calculate spatial explicit current $\mathrm{N}$ and $\mathrm{P}$ losses from agro- ecosystems and compare those with critical $\mathrm{N}$ and $\mathrm{P}$ losses in view of the above mentioned adverse effects. The assessment was made at EU level, country level and at the level of NitroEurope Classification Units (NCUs). NCUs are unique combinations of soil type, administrative region, slope class and altitude class composed of polygons that are a cluster of $1 \mathrm{~km} \times 1 \mathrm{~km}$ pixel.

We used the INTEGRATOR model to calculate the spatial explicit current N and P losses (the year 2010), with critical $\mathrm{N}$ and $\mathrm{P}$ losses to air and water based on critical criteria. For $\mathrm{N}$ these critical losses were related to: (i) ammonia $\left(\mathrm{NH}_{3}\right)$ deposition on neighbouring nature areas in view of habitat quality and biodiversity; (ii) nitrate $\left(\mathrm{NO}_{3}\right)$ leaching in view of drinking water quality, and (iii) $\mathrm{N}$ leaching in view of surface water quality (eutrophication). For $\mathrm{P}$ we used $\mathrm{P}$ runoff to protect surface water from eutrophication. Although $\mathrm{N}$ inputs also cause $\mathrm{N}_{2} \mathrm{O}$ emissions this aspect is not included in the assessment since there are no clear limits for $\mathrm{N}_{2} \mathrm{O}$ emissions, apart from a required reduction target.

\section{MATERIAL AND METHODS}

\subsection{Model and data involved}

Calculations of current $\mathrm{N}$ and $\mathrm{P}$ balances were made with the INTEGRATOR model for approximately 40000 NCUs, being unique combinations of soil type, administrative region, slope class and altitude class composed of polygons that are a cluster of $1 \mathrm{~km}$ x $1 \mathrm{~km}$ pixels (De Vries et al., 2011a; De Vries et al., 2011b). INTEGRATOR includes various sub-models for the prediction of $\mathrm{N}\left(\mathrm{NH}_{3}, \mathrm{NO}_{\mathrm{x}}, \mathrm{N}_{2} \mathrm{O}\right.$ and $\left.\mathrm{N}_{2}\right)$ emissions and $\mathrm{N}$ leaching from (i) housing and manure storage systems and agricultural soils (Velthof et al., 2009), (ii) non-agricultural terrestrial systems, and (iii) an emission deposition matrix for $\mathrm{NH}_{3}$ and $\mathrm{NO}_{x}$, based on the EMEP model (Simpson et al., 2006). For P, the model currently is limited to P inputs by mineral and organic fertilizers (manure and biosolids) and deposition and $\mathrm{P}$ removal by harvest.

\subsection{Assessment of current $N$ and $P$ losses and the comparison with critical $N$ and $P$ losses.}

Critical $\mathrm{NH}_{3}$ emissions to the air in view of biodiversity impacts were based on National $\mathrm{NH}_{3}$ Emission Ceilings, which have been set in order limit the $\mathrm{NH}_{3}$ deposition in order to prevent a decrease in biodiversity. These ceiling are (partly) based on critical nitrogen deposition on nature sites.

Critical $\mathrm{N}$ and $\mathrm{P}$ losses to water were assessed by multiplication of current runoff and leaching rates with critical $\mathrm{N}$ and $\mathrm{P}$ concentrations in leaching water and/or runoff water. We assumed that the current precipitation surplus also holds for the critical losses (no impacts of climate change). The following $\mathrm{N}$ and $\mathrm{P}$ indicators were used to assess critical $\mathrm{N}$ and $\mathrm{P}$ losses:

- Biodiversity impacts: emission ceilings for ammonia $\left(\mathrm{NH}_{3}\right)$ based on the computation of atmospheric dispersion and critical loads for the deposition of $\mathrm{NH}_{3}$ as developed for Europe (Hettelingh et al., 2013) for (i) National Emission Ceilings (NEC) as defined in the European NEC Directive (EC, 2001; EEA, 2012) and (ii) Maximum Feasible Reduction (MFR) by the full implementation of the most efficient abatement technology to reduce $\mathrm{NH}_{3}$ emissions.

- Ground water quality: the critical $\mathrm{NO}_{3}$ concentrations in ground water related to health effects based on the WHO drinking water limit of $50 \mathrm{mg} \mathrm{NO}_{3} \mathrm{l}^{-1}$ or $11.3 \mathrm{mg} \mathrm{NO}_{3}-\mathrm{N} \mathrm{l}^{-1}(\mathrm{WHO}, 2004)$ and the EU guideline value of $25 \mathrm{mg} \mathrm{NO}_{3}-\mathrm{N}^{-1}$.

- Surface water quality (eutrophication): dissolved total $\mathrm{N}$ and $\mathrm{P}$ concentrations in surface water of 1.0 and $2.5 \mathrm{mg} \mathrm{N}^{-1}$ and $0.15 \mathrm{mg} \mathrm{P}^{-1}$ (Camargo and Alonso, 2006; Laane, 2005; Liu et al., 2011). 
For $\mathrm{NH}_{3}$ emission the calculated current $\mathrm{NH}_{3}$ emissions were up-scaled to Member State (MS) level and directly compared with the National Emission Ceilings (NEC) and Maximum Feasible reductions (MFR). The current NECs are defined for the period up to 2020 and aim at reducing the ecosystem area where the critical loads for $\mathrm{N}(\mathrm{CLN})$ are exceeded. The EU's long-term objective is to eliminate the exceedance of CLN for ecosystems.

For $\mathrm{N}$ leaching and $\mathrm{N}$ runoff we compared the current losses with the critical leaching and runoff, which were calculated by multiplying the precipitation surplus with a critical $\mathrm{NO}_{3}$ concentration in upper groundwater of 50 and $25 \mathrm{mg} \mathrm{NO}_{3} \mathrm{l}^{-1}$ and a critical $\mathrm{N}$ concentration in stagnant surface water of 1 and 2.5 mg. $\mathrm{N}^{-1}$ respectively.

For $\mathrm{P}$ runoff we compared the calculated current $\mathrm{P}$ surplus (i.e. $\mathrm{P}$ input minus $\mathrm{P}$ uptake) with the critical runoff, which was calculated by multiplying the precipitation surplus with a critical $\mathrm{P}$ concentration in draining water towards surface water of $0.15 \mathrm{mg} \mathrm{P} \mathrm{l}^{-1}$. We took the $\mathrm{P}$ surplus, because from a long term sustainable perspective the $\mathrm{P}$ accumulation must be close to zero.

\section{RESULTS}

\subsection{Current $\mathbf{N}$ and $\mathbf{P}$ balances}

The calculated annual $\mathrm{N}$ and P budgets at EU-27 level for the year 2010 are given in Table 1. Results indicate that the highest $\mathrm{N}$ input is from mineral fertilizer (10.8 Mton $\mathrm{N})$ followed by animal manure $(8.7 \mathrm{Mton} \mathrm{N})$, whereas for $\mathrm{P}$ highest inputs from animal manure (1.5 Mton P) exceed those from chemical fertilizer (1.1 Mton $\mathrm{P}$ ). About $55 \%$ of the total $\mathrm{N}$ input is removed by harvested crops, while this is almost $80 \%$ for $\mathrm{P}$. Highest $\mathrm{N}$ losses are $\mathrm{N}_{2}$ emission resulting from denitrification, whereas most of the $\mathrm{P}$ surplus accumulates in the soil. In Table 1 also the total critical losses for $\mathrm{NH}_{3}$ emission, $\mathrm{N}$ and $\mathrm{P}$ leaching to groundwater and $\mathrm{N}$ and $P$ runoff to surface water are given.

The spatial distribution of the current $\mathrm{N}$ and $\mathrm{P}$ surpluses (Figure 1) are quite variable across the EU-27, both within a country and between countries. As such, maps with surpluses (inputs minus crop removal) only give an indication of potential risks for losses of $\mathrm{N}$ and $\mathrm{P}$ to air (in case of $\mathrm{N}$ ), soil and water. To assess the actual risk it is needed to quantify the 'real' losses in terms of $\mathrm{N}$ emissions to the atmosphere and $\mathrm{N}$ and $\mathrm{P}$ losses to water, as will be shown in the next section, which are highly influenced by soil properties, climate and relief. The extent of $\mathrm{N}_{2} \mathrm{O}, \mathrm{NO}_{\mathrm{x}}$ and $\mathrm{N}_{2}$ emission for example depends on the occurrence of wet circumstance (Lesschen et al., 2011) whereas the accumulation of $\mathrm{P}$ is partly controlled by the occurrence of iron and aluminium in soils (Schoumans and Chardon, 2015).High surpluses of $\mathrm{N}$ and $\mathrm{P}$ are mostly the result of the occurrence of high livestock density and reflect $\mathrm{N}$ and $\mathrm{P}$ manure inputs over Europe. The spatial patterns of $\mathrm{N}$ and $\mathrm{P}$ surplus are broadly similar (Figure 1), but dissimilarities exist for southern MS (e.g. Spain, Italy and Greece), where low $\mathrm{N}$ surpluses coincide with high $\mathrm{P}$ surpluses. This was due to relatively low $\mathrm{N}$ inputs in combination with relatively high $\mathrm{P}$ inputs by mineral fertilizers in those countries.

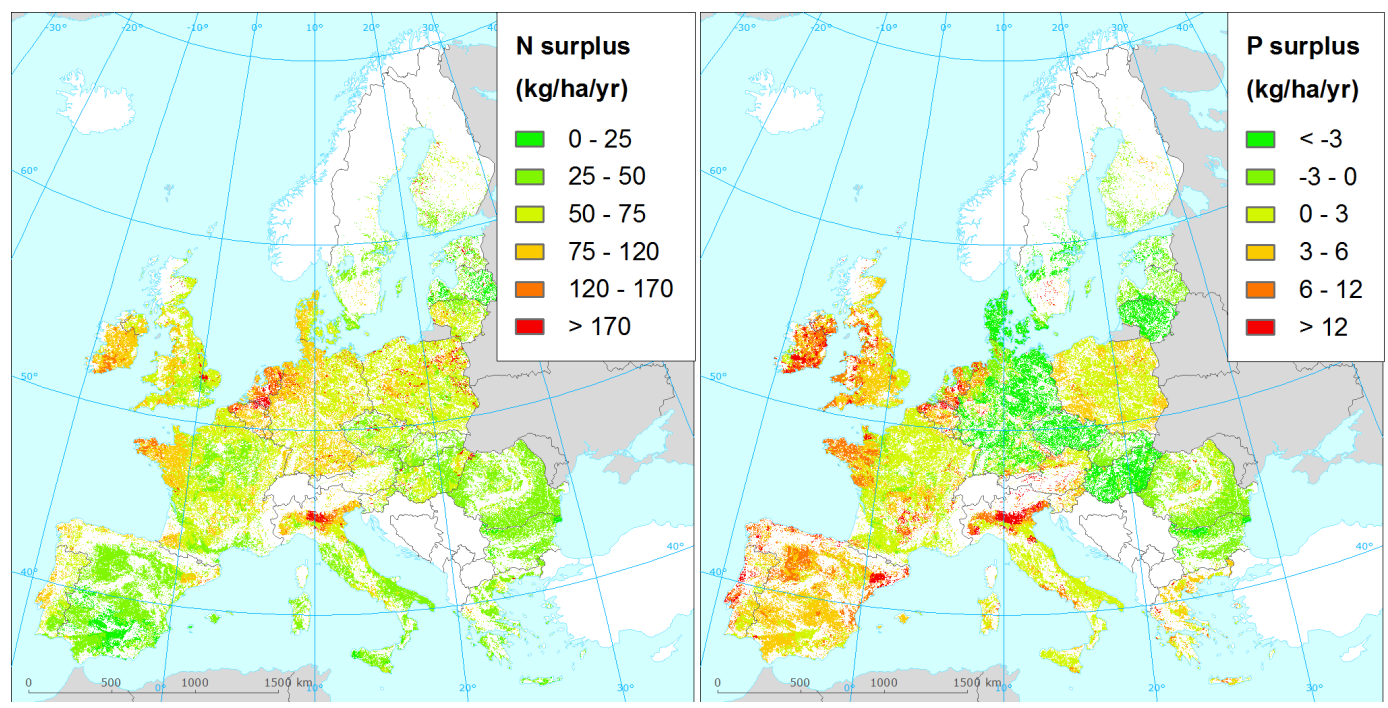

Figure 1. N (left) and P (right) surpluses at NCU level in 2010 as calculated by INTEGRATOR. 
Kros et al., An assessment of current nitrogen and phosphorus losses from European agricultural soils

Table 1. Annual $\mathrm{N}$ and $\mathrm{P}$ budgets of agricultural land in EU-27 in 2010, including $\mathrm{N}\left(\mathrm{NH}_{3}, \mathrm{~N}_{2} \mathrm{O}, \mathrm{NO}_{\mathrm{x}}\right.$ and $\mathrm{N}_{2}$ ) emissions from housing systems and from soil, calculated by INTEGRATOR. Also given are the critical losses for $\mathrm{NH}_{3}$ emission, $\mathrm{NO}_{3}$ leaching to groundwater and $\mathrm{N}$ and $\mathrm{N}$ runoff to surface water.

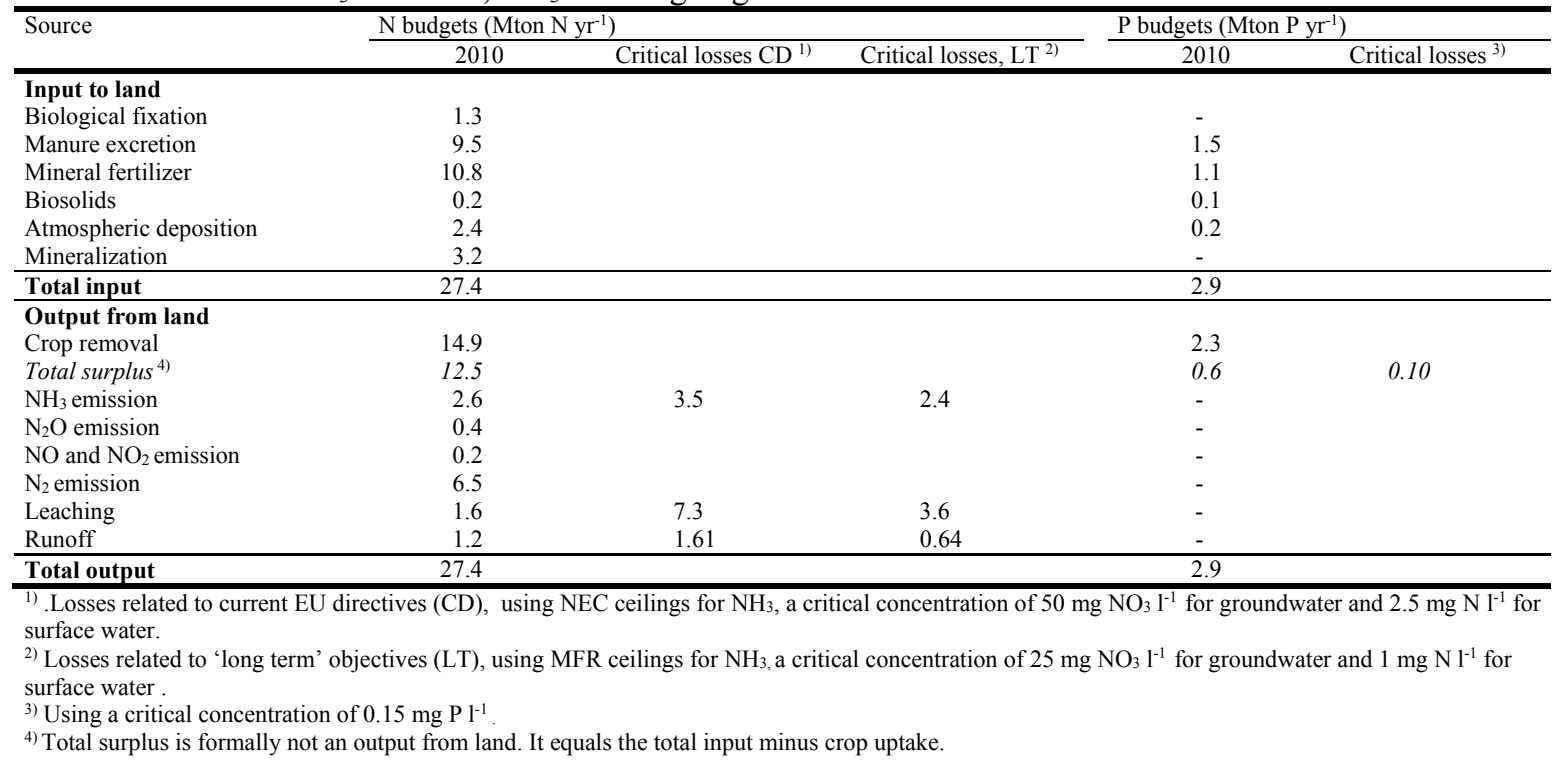

\subsection{Current and critical $\mathbf{N}$ and $P$ losses at MS level}

For $\mathrm{NH}_{3}$ we compared the current total $\mathrm{NH}_{3}$ emission at MS level both with the NEC and MFR emission (Figure 2). In most MSs the current emission is already below the NEC (values $<0$ ), whereas for the MFR is exceeded in almost $50 \%$ of the MS. However, the NEC does not guarantee that the critical deposition of N (CLN) is not exceeded at a regional level. In areas with a high $\mathrm{N}$ input, especially by manure, the CLN can be exceeded at a regional level even if criteria for NEC or MFR are met at national level (Hettelingh et al., 2013). The spatial distribution of $\mathrm{NH}_{3}$ emissions (not shown) and thus of CLN exceedances, reasonably coincides with the distribution of the $\mathrm{N}$ surplus (see Figure 1).

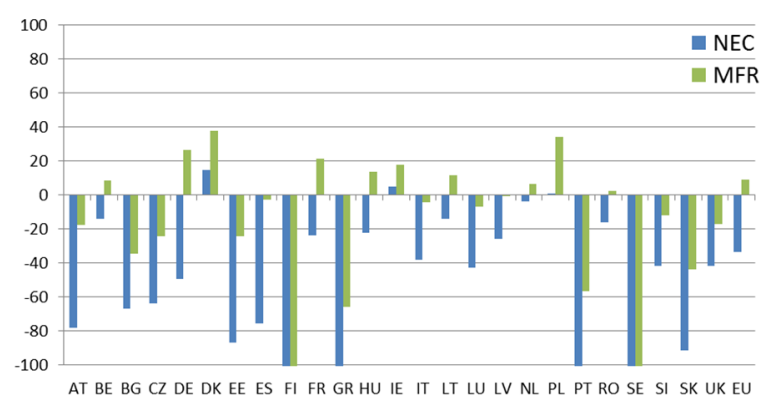

Figure 2. Relative difference of the current (2010) $\mathrm{NH}_{3}$ emissions with NEC and MFR emissions per MS as calculated with INTEGRATOR. Positive numbers indicate the degree to which current $\mathrm{NH}_{3}$ emissions exceeds the critical $\mathrm{NH}_{3}$ emissions.

The comparison of current $\mathrm{NO}_{3}$ leaching to groundwater with the critical leaching concentration at MS level shows that current losses remain below the critical losses for both criteria in almost all MS (Figure 3, left). Notable exceptions are Denmark, Netherlands and Poland. For surface water the situation is different (Figure 3 , right). Positive numbers indicate the degree to which current leaching rate exceeds the critical leaching rate. Contrary to $\mathrm{N}$ runoff to surface water, the current $\mathrm{P}$ runoff losses at MS level exceed the critical losses

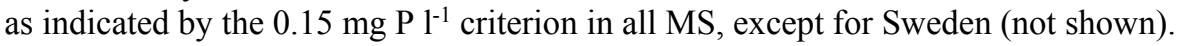



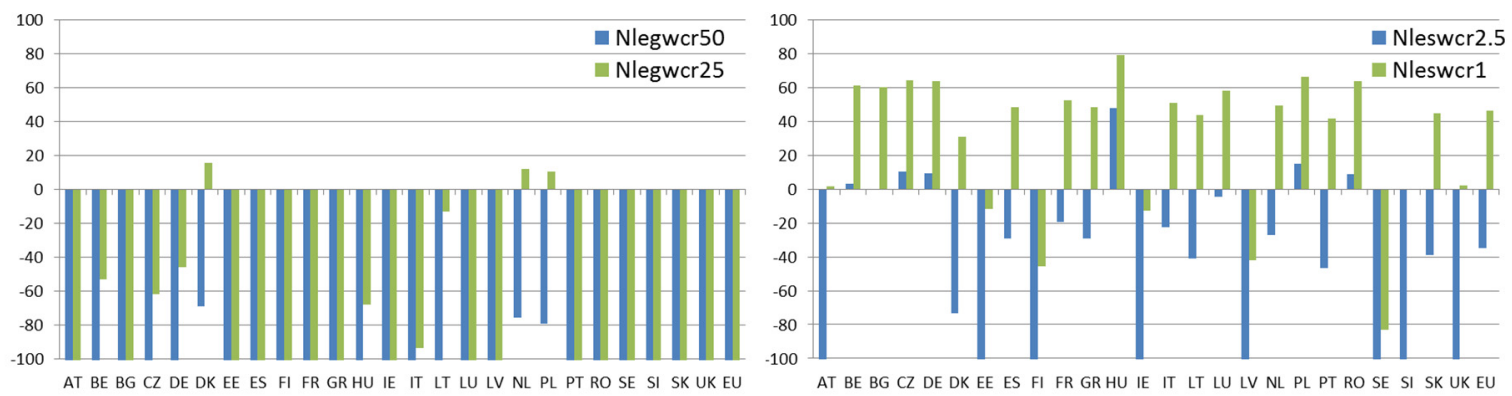

Figure 3. Relative difference of the current (2010) with the critical $\mathrm{NO}_{3}$ leaching to groundwater (left) and $\mathrm{N}$ runoff to surface water (right) per MS.

\subsection{Current and critical $\mathbf{N}$ and $P$ losses to ground and surface water at NCU level}

The spatial distribution of nitrate leaching fluxes and the exceedance of the critical leaching flux related to a critical $\mathrm{NO}_{3}$ concentration in groundwater of $50 \mathrm{mg} \mathrm{NO}_{3} \mathrm{l}^{-1}$ are given in Figure 4. The highest $\mathrm{N}$ losses to groundwater occur in the well-drained areas in Central Europe and the Po valley in Northern Italy (Figure 4, left). These are generally also the areas with high $\mathrm{N}$ surpluses (Figure 1) and with high livestock density. These areas do not necessarily coincide, however, with areas where the critical nitrate leaching flux to groundwater is exceeded (Figure 4, right). This is especially true for Spain, Southern Italy, Romania and Greece, being MS with low precipitation surplus resulting in high $\mathrm{NO}_{3}$ concentrations, even at low $\mathrm{N}$ inputs.

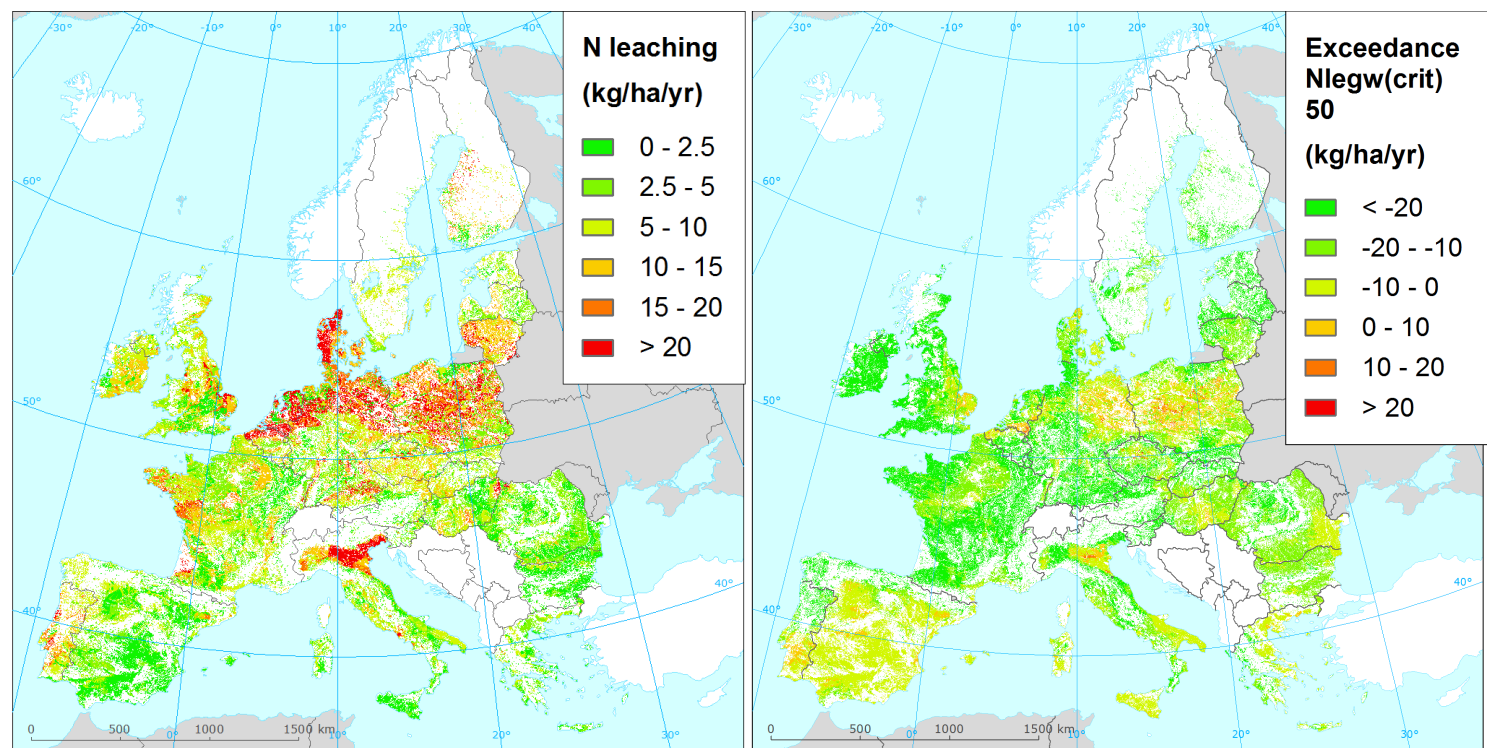

Figure 4. Spatial distribution of the current (2010) $\mathrm{NO}_{3}$ leaching flux to groundwater (left) at NCU level and the difference with the critical leaching flux related to a critical $\mathrm{NO}_{3}$ concentration in groundwater of $50 \mathrm{mg}$ $\mathrm{NO}_{3} 1^{-1}$ (right) as calculated with INTEGRATOR.

Maps with the $\mathrm{N}$ runoff flux and the exceedance of the critical runoff flux related to a critical $\mathrm{N}$ concentration in surface water of $2.5 \mathrm{mg} \mathrm{N} \mathrm{l}^{-1}$ are given in Figure 5. The current $\mathrm{N}$ runoff to surface water is more equally distributed than the leaching to groundwater, and higher runoff rates are located in the mountainous Central parts of Europe with steep slopes and shallow soils. The exceedance of the critical $\mathrm{N}$ runoff related to the 2.5

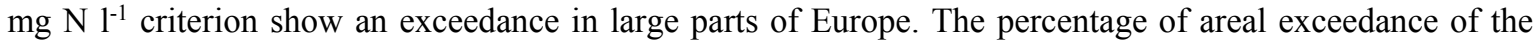
critical leaching to groundwater and runoff to surface water per MS are given in Figure 6. The data show that the areal exceedance for groundwater ranges from 0 to $20 \%$ for the $50 \mathrm{mg} \mathrm{NO}_{3} \mathrm{l}^{-1}$ criterion and from 0 to $60 \%$ for the $25 \mathrm{mg} \mathrm{NO}_{3} \mathrm{l}^{-1}$ criterion. For surface water the areal exceedances are clearly higher and range from 19 to $94 \%\left(1 \mathrm{mg} \mathrm{N}^{-1}\right)$ and from 2 to $77 \%\left(2.5 \mathrm{mg} \mathrm{N}^{-1}\right)$.

Maps with the P runoff flux and the exceedance of the critical runoff flux related to a critical P concentration in surface water of $0.15 \mathrm{mg} \mathrm{P}^{-1}$ are given in Figure 7. High P losses occur in the western and southern part of Europe. Contrary to $\mathrm{N}$ runoff, the exceedance of critical $\mathrm{P}$ runoff coincides with the current $\mathrm{P}$ runoff to surface water and the percentage of areal exceedance of the critical P runoff is higher and ranges from 10 to $100 \%$ (Figure 8). 
Kros et al., An assessment of current nitrogen and phosphorus losses from European agricultural soils

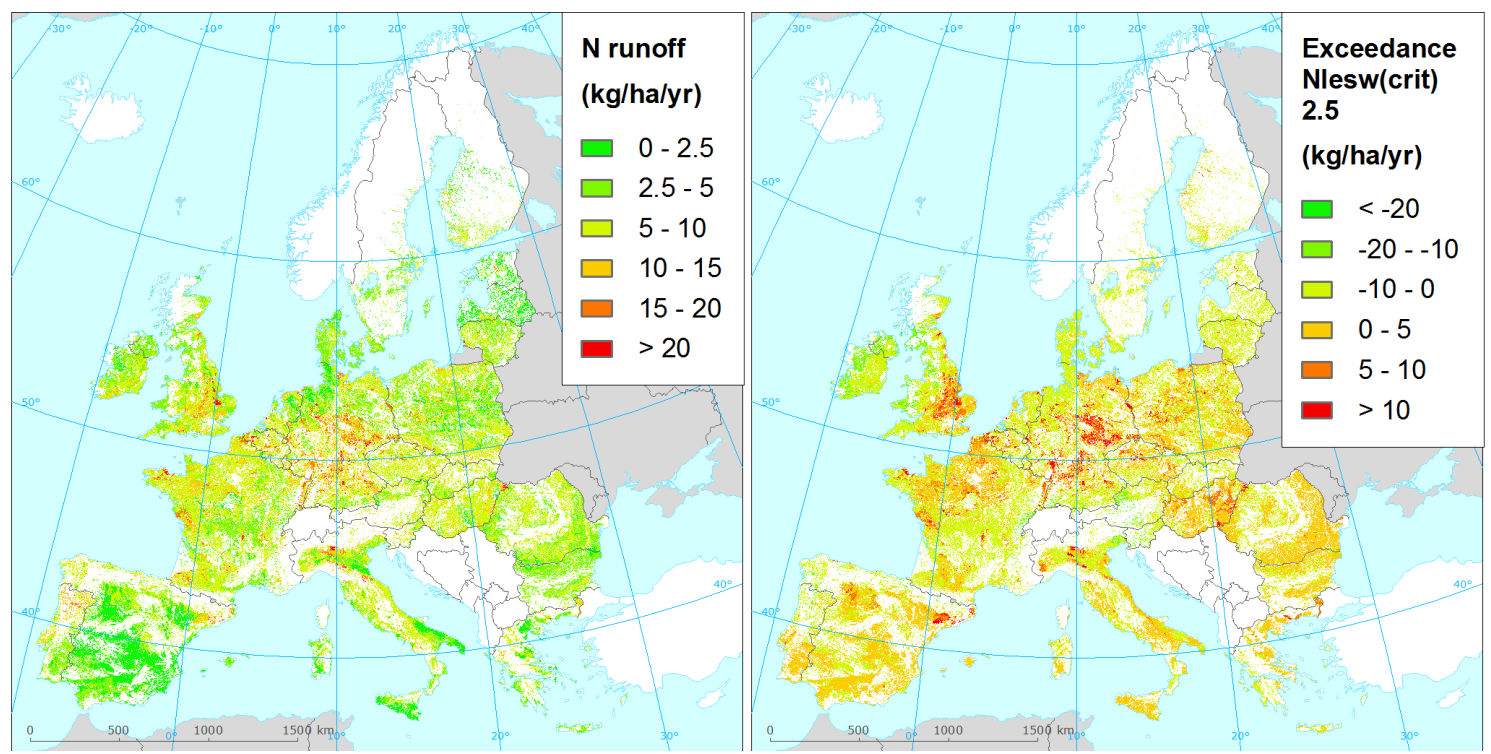

Figure 5. Spatial distribution of the current (2010) N runoff flux to surface water (left) at NCU level and the difference with the critical leaching flux related to a critical $\mathrm{N}$ concentration in surface water of $2.5 \mathrm{mg} \mathrm{N}^{-1}$ (right) as calculated with INTEGRATOR.
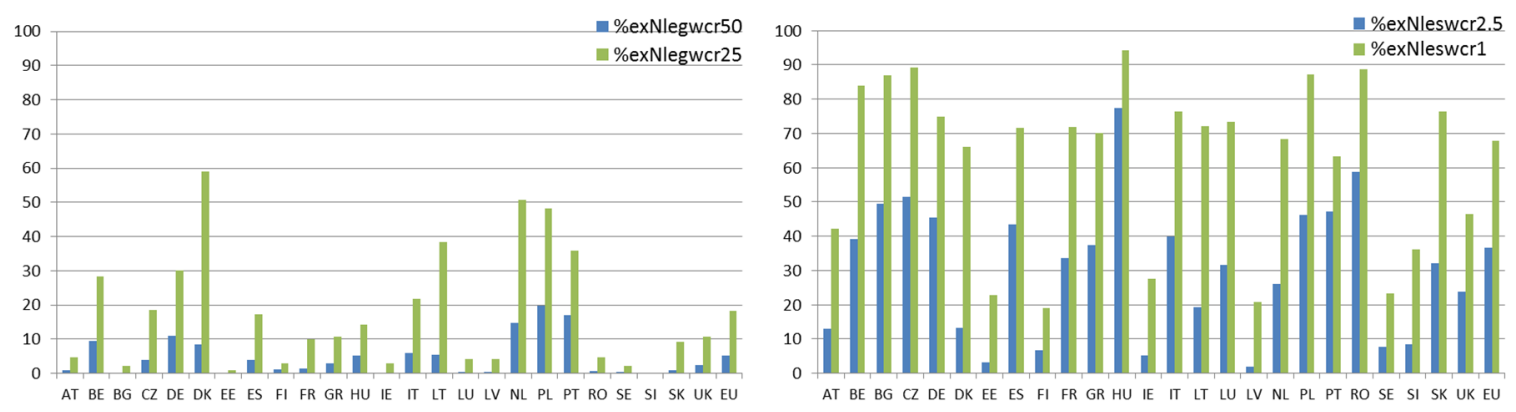

Figure 6. NCU level based areal exceedance of the critical $\mathrm{NO}_{3}$ leaching to groundwater (left) and the critical N runoff to surface water (right) per EU-27 in 2010 as calculated with INTEGRATOR.

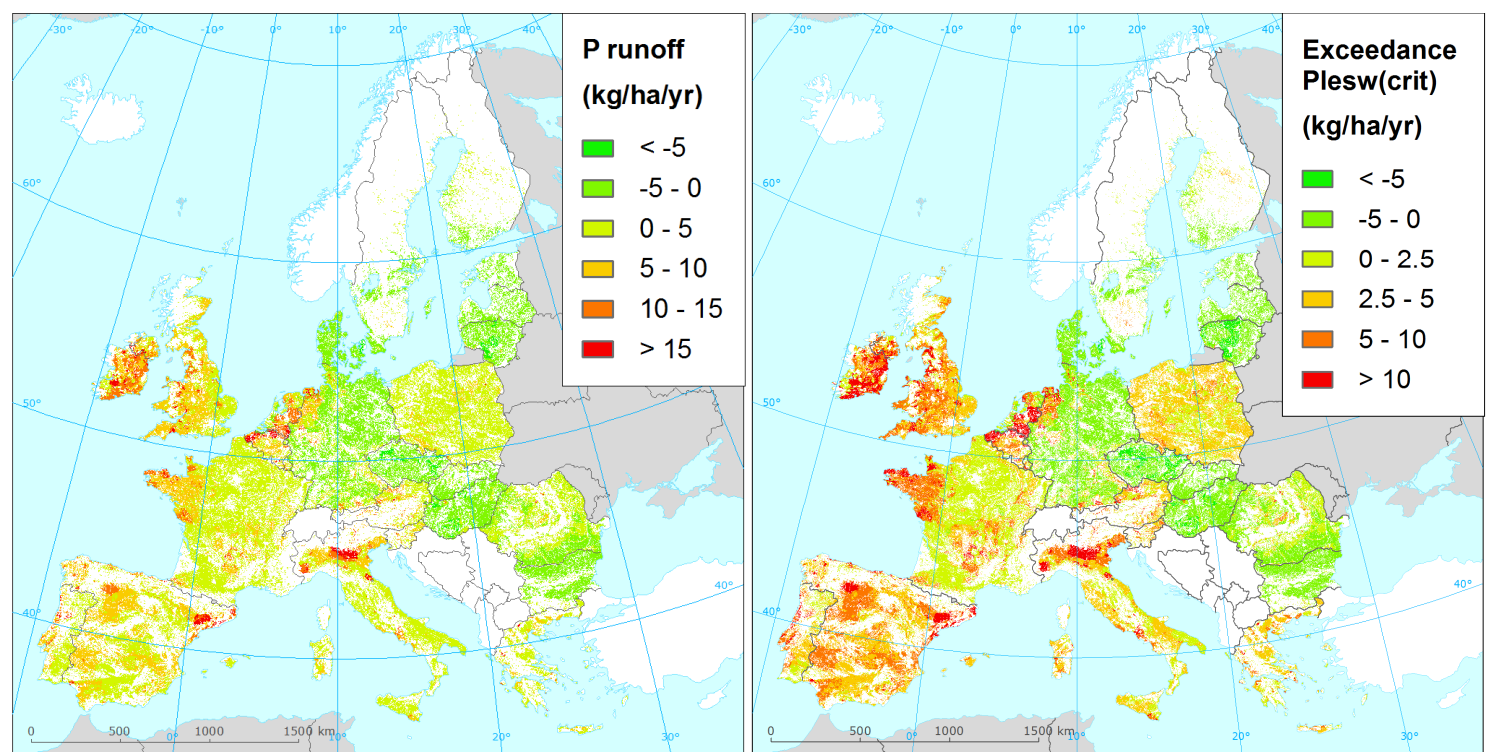

Figure 7. Spatial distribution of the P runoff flux (2010) to surface water (left) at NCU level and the difference with the critical leaching flux related to a critical $\mathrm{P}$ concentration in surface water of $0.15 \mathrm{mg} \mathrm{P}^{-1}$ (right). 


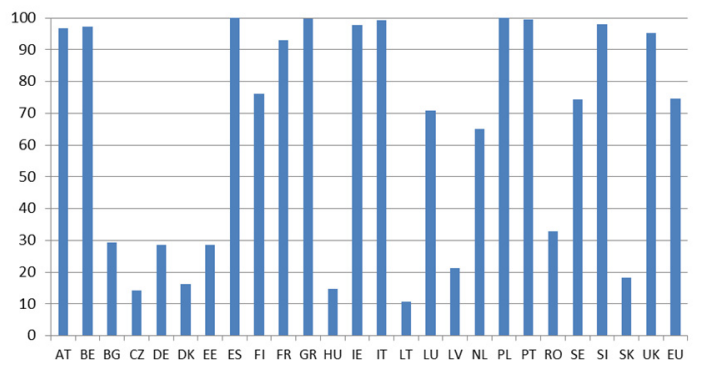

Figure 8. Exceedance of the critical P runoff to surface water for EU-27 upscaled from NCU level in 2010.

\section{CONCLUSIONS}

Estimates of current (2010) N and P surpluses show that they are highly spatially variable and largely related to the livestock distribution, which is mostly correlated with regions with a high mineral fertilizer inputs.

Critical losses at MS level are hardly ever exceeded, but the exceedances of critical losses may still occur at regional level within a MS. Hence, in addition to the control of losses at national level, environmental analyses at higher spatial resolution are required for an adequate protection of natural areas and quality of ground- and surface waters.

The degree of exceedance at NCU level decreases in the direction of potential P runoff to surface water (75\%), $\mathrm{N}$ runoff ( $68 \%$ for the $1 \mathrm{mg} \mathrm{N}^{-1}$ and $37 \%$ for the $2.5 \mathrm{mg} \mathrm{N}^{-1}$ criterion) to surface water and $\mathrm{NO}_{3}$ leaching to groundwater ( $18 \%$ for the $25 \mathrm{mg} \mathrm{NO}_{3} \mathrm{l}^{-1}$ and $5 \%$ for the $50 \mathrm{mg} \mathrm{NO}_{3} \mathrm{l}^{-1}$ criterion).

\section{ACKNOWLEDGMENTS}

This research has been funded by the European Environmental Agency.

\section{REFERENCES}

Camargo, J.A. and Alonso, A., 2006. Ecological and toxicological effects of inorganic nitrogen pollution in aquatic ecosystems: A global assessment. Environment International, 32(6): 831-849.

De Vries, W. et al., 2011a. Comparison of land nitrogen budgets for European agriculture by various modeling approaches. Environmental Pollution, 159(11): 3254-3268.

De Vries, W. et al., 2011b. Geographic variation in terrestrial nitrogen budgets across Europe. In: M.A. Sutton et al. (Editors), The European Nitrogen Assessment. Cambridge University Press, Chapter 15, Cambridge, UK, pp. 317-344.

EC, 2001. Directive 2001/81/EC of the European Parliament and of the Council of 23 October 2001 on national emission ceilings for certain atmospheric pollutants. European Commision, Brussel.

EEA, 2012. NEC Directive Status Report 2011. Technical report 6/2012, European Environment Agency.

Hettelingh, J.-P. et al., 2013. Assessing interim objectives for acidification, eutrophication and ground-level ozone of the EU National Emissions Ceilings Directive with 2001 and 2012 knowledge. Atmospheric Environment, 75: 129-140.

Laane, R.W.P.M., 2005. Applying the critical load concept to the nitrogen load of the river Rhine to the Dutch coastal zone. Estuarine, Coastal and Shelf Science, 62(2): 487-493.

Lesschen, J.P., Velthof, G.L., de Vries, W. and Kros, J., 2011. Differentiation of nitrous oxide emission factors for agricultural soils. Environmental Pollution, 159(11): 3215-3222.

Liu, C., Kroeze, C., Hoekstra, A.Y. and Gerbens-Leenes, W., 2011. Past and future trends in grey water footprints of anthropogenic nitrogen and phosphorus inputs to major world rivers. Ecological Indicators, 18: 42-49.

Schoumans, O.F. and Chardon, W.J., 2015. Phosphate saturation degree and accumulation of phosphate in various soil types in The Netherlands. Geoderma, 237: 325-335.

Simpson, D. et al., 2006. Deposition and emissions of reactive nitrogen over European forests: A modelling study. Atmospheric Environment, 40(29): 5712-5726.

Velthof, G.L. et al., 2009. Integrated assessment of nitrogen emission losses from agriculture in EU-27 using MITERRA-EUROPE. Journal of Environmental Quality, 38(2): 1-16.

WHO, 2004. Guidelines for Drinking-Water Quality. Volume 1: Recommendations, Geneva. 